\title{
Study on the effect of magnetic field treatment of newly isolated Paenibacillus sp.
}

\author{
Jie Li ${ }^{1}$, Yanli Yi ${ }^{1 *}$, Xilei Cheng ${ }^{2}$, Dageng Zhang ${ }^{1}$ and Muhammad Irfan $^{3}$
}

\begin{abstract}
Background: Symbiotic nitrogen fixation in plants occurs in roots with the help of some bacteria which help in soil nitrogen fertility management. Isolation of significant environment friendly bacteria for nitrogen fixation is very important to enhance yield in plants.

Results: In this study effect of different magnetic field intensity and treatment time was studied on the morphology, physiology and nitrogen fixing capacity of newly isolated Paenibaccilus sp. from brown soil. The bacterium was identified by $16 \mathrm{~S}$ rDNA sequence having highest similarity (99\%) with Paenibacillus sp as revealed by BLAST. Different magnetic intensities such as 100mT, 300mT and 500mT were applied with processing time of 0, 5, 10, 20 and 30 minutes. Of all these treatment $300 \mathrm{mT}$ with processing time of 10 minutes was found to be most suitable treatment. Results revealed that magnetic treatment improve the growth rate with shorter generation time leading to increased enzyme activities (catalase, peroxidase and superoxide dismutase) and nitrogen fixing efficiencies. High magnetic field intensity $(500 \mathrm{mT})$ caused ruptured cell morphology and decreased enzyme activities which lead to less nitrogen fixation.
\end{abstract}

Conclusion: It is concluded that appropriate magnetic field intensity and treatment time play a vital role in the growth of soil bacteria which increases the nitrogen fixing ability which affects the yield of plant. These results were very helpful in future breading programs to enhance the yield of soybean.

Keyword: Magnetic treatment; Paenibaccilus sp; Catalase; Peroxidase; Superoxide dismutase

\section{Background}

Paenibacillus genus of bacteria was first included in Bacillus genus and then reclassified to a separate genus in 1993 (Ash et al. 1993). These bacteria found in variety of environments like soil, water, forage, rhizosphere, insect larvae, vegetable matter and in clinical samples (McSpadden Gardener 2004, (Montes et al. 2004; Ouyang et al. 2008; Lal \& Tabacchioni 2009)). These bacteria are of prime importance in agriculture for nitrogen fixation and industrial importance due to production of antibiotics and enzymes (Mavingui \& Heulin 1994; Von der Weid et al. 2003). These bacteria produce plant growth hormones, suppress phytopathogens and solubilize

\footnotetext{
*Correspondence: yiyanli@126.com

${ }^{1}$ Key Laboratory of Preservation of Northeast Cultivated Land, Ministry of Agriculture, National Engineering Laboratory for Efficient Utilization of Soil and Fertilizer, College of Land and Enviroment, Shenyang Agricultural University, 120 dongling road, Shenyang 110866, Liaoning, China Full list of author information is available at the end of the article
}

organic phosphate (Mavingui \& Heulin 1994; Lebuhn et al. 1997; Pires \& Seldin 1997).

Nitrogen is very essential nutrient for the growth of plants. So, these bacteria fix nitrogen from the air and provide this nitrogen to plants in the form of ammonium ions or other nitrogenous compounds essential for growth. From this symbiotic association, plant provides some organic compounds synthesized from photosynthesis (Sawada et al. 2003). These bacteria not only fix the nitrogen but also enrich the soil fertility, increase plant production, and improve the quality, degrade organic pollutants and production of vitamin B series compounds (Sierra et al. 1999; Agus et al. 2000). The nitrogen deficiency was recovered by these rhizobia (Fisher \& Long 1992). In this process, plant produced some reactive oxygen species including the hydrogen peroxide and hydroxyl radicals and superoxide anion by defence reaction (Lamb \& Dixon 1997; Santos et al. 2001). So it was necessary to study the rhizobia catalase, peroxidase and superoxide dismutase active changes. 


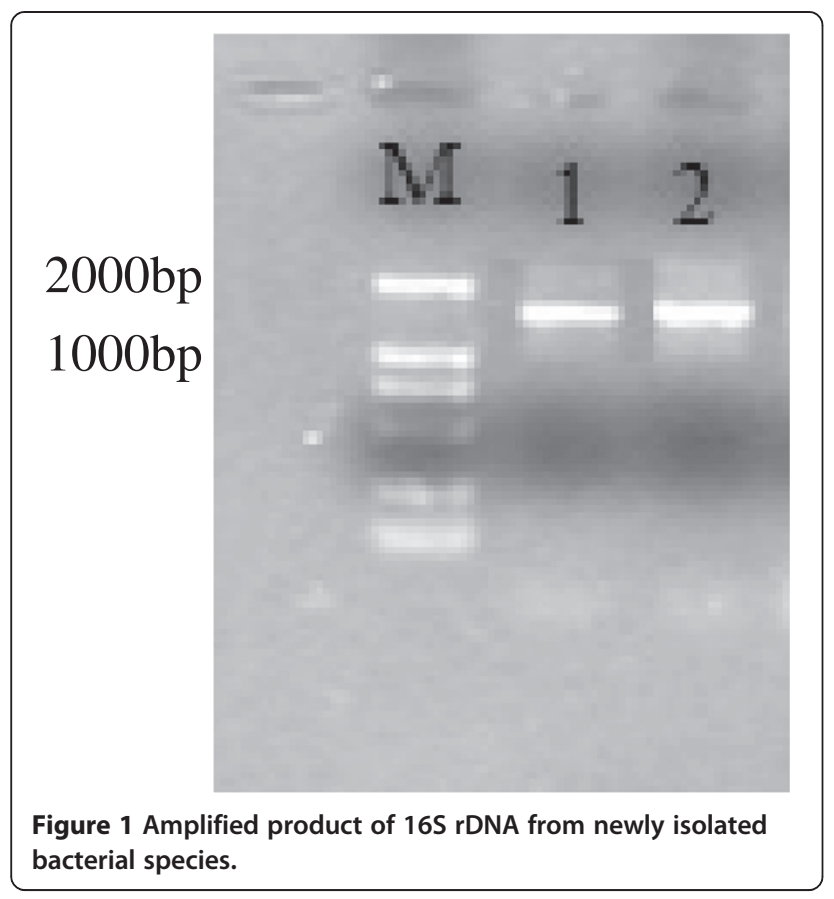

Figure 1 Amplified product of 16S rDNA from newly isolated bacterial species.
A lot of research showed that the magnetic treatments have certain stimulative effect on crop production and development and, it also affect the genetic quality of seeds ((Zhu et al. 1996; Liu et al. 1996; Yan et al. 1997; He et al. 1999; Mao et al. 2002); Jia et al. 2002; (Liu et al. 2003)). Enzyme as protein with catalytic activity has an important role in the life process, and as a catalyst it was increasingly being attention (Cheng et al. 2007). Magnetic field on the influence of the enzyme activity has been reported (He et al. 1998; Li et al. 2007; Hua et al. 2008), and this area now attracts more and more people's attention, but most of these studies focused on animals, plants and very little research on bacteria. So this study was aimed to check the effect of magnetic field on soybean rhizobia isolated from brown soil and their enzyme activities (peroxidase, catalase and superoxide dismutase) under the influence various intensity of magnetic treatment.

\section{Methods}

\section{Materials}

The Brown soil samples were collected from Shenyang Agriculture University, Shenyang Liaoning P.R. China. The samples were kept in sterile plastic bags and transferred aseptically to the lab.

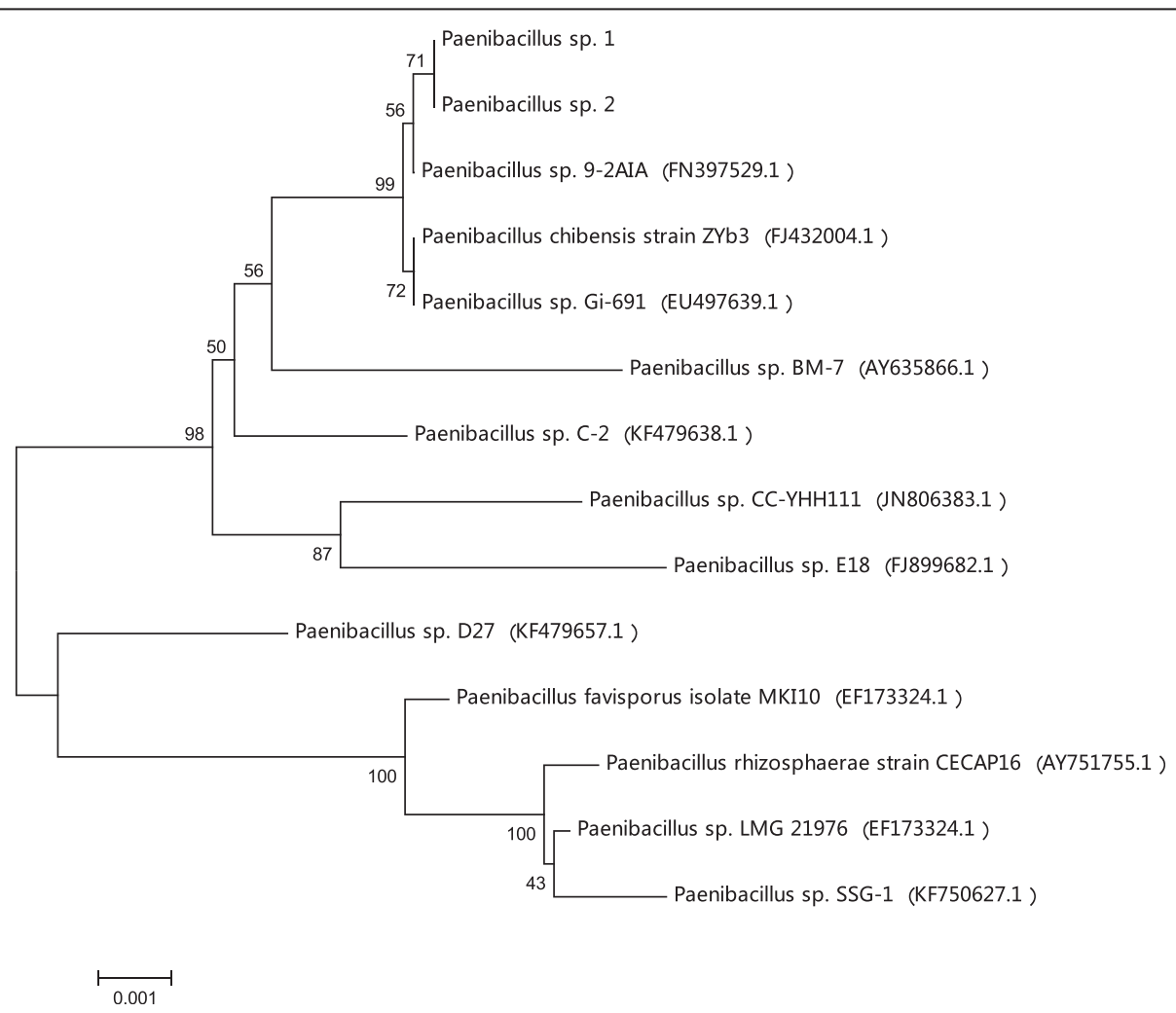

Figure 2 Neighbor-joining phylogenetic analysis of $16 \mathrm{~S}$ rDNA sequences (1442 bp) of newly isolated Paenibacillus sp. compared with the sequence of standard strains. The bar represents a $0.002 \%$ of nucleotide variance. 
Table 1 Effect of magnetic field treated soil on soybean nodular and nitrogen content

\begin{tabular}{|c|c|c|c|c|c|c|c|}
\hline \multicolumn{2}{|l|}{ Treatment } & \multicolumn{2}{|c|}{ Bacterial dry weight } & \multicolumn{2}{|c|}{ Effective number of root nodule } & \multicolumn{2}{|c|}{ Total nitrogen } \\
\hline $\begin{array}{l}\text { Magnetic field } \\
\text { (mT) }\end{array}$ & $\begin{array}{l}\text { Time } \\
(\min )\end{array}$ & $\begin{array}{l}\text { Weight } \\
\left(\mathrm{g} \text { dry wt pl }{ }^{-1}\right)\end{array}$ & $\begin{array}{l}\text { Percentage } \\
\text { change (\%) }\end{array}$ & $\begin{array}{l}\text { Amount } \\
\text { (No./plant) }\end{array}$ & $\begin{array}{l}\text { Percentage } \\
\text { change (\%) }\end{array}$ & $\begin{array}{l}\text { Content } \\
(\mathrm{mg} / \mathrm{g})\end{array}$ & $\begin{array}{l}\text { Percentage } \\
\text { change (\%) }\end{array}$ \\
\hline Control (CK) & & $0.06^{\mathrm{h}}$ & - & $7 \pm 1.23$ & - & $3.23 \pm 0.12$ & - \\
\hline \multirow[t]{4}{*}{100} & 5 & $0.20^{c}$ & 233 & $24 \pm 3.47$ & 243 & $3.46 \pm 0.13$ & 7.12 \\
\hline & 10 & $0.19^{d}$ & 217 & $18 \pm 1.76$ & 157. & $3.51 \pm 0.12$ & 8.67 \\
\hline & 20 & $0.17^{\mathrm{e}}$ & 183 & $17 \pm 1.84$ & 143 & $3.35 \pm 0.11$ & 3.72 \\
\hline & 30 & $0.15^{f}$ & 150 & $16 \pm 1.34$ & 129 & $3.25 \pm 0.12$ & 0.62 \\
\hline \multirow[t]{4}{*}{300} & 5 & $0.27^{\mathrm{a}}$ & 350 & $37 \pm 1.63$ & 429 & $4.33 \pm 0.17$ & 34.06 \\
\hline & 10 & $0.26^{\mathrm{b}}$ & 333 & $28 \pm 2.95$ & 300 & $4.55 \pm 0.15$ & 40.87 \\
\hline & 20 & $0.15^{f}$ & 150 & $24 \pm 2.58$ & 243 & $3.58 \pm 0.13$ & 10.84 \\
\hline & 30 & $0.09^{9}$ & 50 & $13 \pm 1.72$ & 86 & $3.51 \pm 0.16$ & 8.67 \\
\hline \multirow[t]{4}{*}{500} & 5 & $0.04^{j}$ & -33 & $7 \pm 1.25$ & 0 & $3.34 \pm 0.13$ & 3.41 \\
\hline & 10 & $0.06^{h}$ & 0 & $7 \pm 1.13$ & 0 & $3.25 \pm 0.12$ & 0.62 \\
\hline & 20 & $0.05^{i}$ & -17 & $6 \pm 1.13$ & -14 & $3.17 \pm 0.11$ & -1.86 \\
\hline & 30 & $0.05^{i}$ & -17 & $7 \pm 1.12$ & 0 & $3.14 \pm 0.13$ & -2.79 \\
\hline
\end{tabular}

The different letters show significant difference $(P<0.05)$.

\section{Isolation of Paenibacillus}

The Paenibacillus sp. were isolated using standard procedures, and were purified by repeatedly streaking the bacteria on yeast extract-mannitol agar (YMA) medium (Vincent 1970) and stored at $4^{\circ} \mathrm{C}$.

\section{Molecular identification of Paenibacillus}

Genomic DNA of the newly isolated bacterial strain was extracted by method as described by Ausubel et al. (1994). The DNA was amplified using universal primers 27 F:5' -GAGAGTTTGATCCTGGCTCAG-3'

Table 2 The magnetic treatment of soybean purification number and generation of rhizobium time influence

\begin{tabular}{|c|c|c|c|c|c|}
\hline \multicolumn{2}{|l|}{ Treatment } & \multicolumn{2}{|c|}{ Paenibacillus sp. I } & \multicolumn{2}{|c|}{ Paenibacillus sp. II } \\
\hline $\begin{array}{l}\text { Magnetic } \\
\text { field (mT) }\end{array}$ & $\begin{array}{l}\text { Time } \\
\text { (min) }\end{array}$ & Number & $\begin{array}{l}\text { Generation of } \\
\text { Paenibacillus } \\
\text { sp. (h) }\end{array}$ & Number & $\begin{array}{l}\text { Generation of } \\
\text { Paenibacillus } \\
\text { sp. (h) }\end{array}$ \\
\hline CK & & 42 & 10.0 & 40 & 3.9 \\
\hline \multirow[t]{4}{*}{100} & 5 & 65 & 8.6 & 75 & 3.0 \\
\hline & 10 & 101 & 8.2 & 68 & 3.1 \\
\hline & 20 & 79 & 8.4 & 62 & 3.3 \\
\hline & 30 & 55 & 8.6 & 64 & 3.5 \\
\hline \multirow[t]{4}{*}{300} & 5 & 85 & 8.0 & 122 & 3.1 \\
\hline & 10 & 127 & 8.0 & 83 & 2.8 \\
\hline & 20 & 95 & 8.1 & 77 & 3.1 \\
\hline & 30 & 66 & 8.1 & 81 & 3.1 \\
\hline \multirow[t]{4}{*}{500} & 5 & 94 & 9.6 & 115 & 3.8 \\
\hline & 10 & 102 & 9.6 & 84 & 3.9 \\
\hline & 20 & 86 & 9.8 & 82 & 3.9 \\
\hline & 30 & 42 & 9.7 & 78 & 4.0 \\
\hline
\end{tabular}

and 1492R:5' -GGYTACCTTGTTACGACTT-3'. PCR reactions were performed in $50 \mathrm{l}$ volume containing $1 \mu \mathrm{L}$ template DNA, $4 \mu \mathrm{L} \mathrm{MgCl}_{2}(25 \mathrm{mmol} / \mathrm{L}), 5 \mu \mathrm{L}$ $10 \times$ PCR buffer $\left(\mathrm{Mg}^{2+}\right.$ free $), 4 \mu \mathrm{L} \mathrm{dNTP}(10 \mathrm{mmol} / \mathrm{L})$, $1 \mu \mathrm{L}$ of each primer $(10 \mu \mathrm{mol} / \mathrm{L}), 0.5 \mu \mathrm{L}$ of TaqDNA polymerase $(5 \mathrm{u} / \mu \mathrm{L})$ and $33.5 \mu \mathrm{L} \mathrm{ddH}_{2} \mathrm{O}$. PCR amplification conditions as follows: Initial denaturation at $94^{\circ} \mathrm{C}$ for $5 \mathrm{~min}$ followed by 30 cycles of denaturation at $94^{\circ} \mathrm{C}$ for $30 \mathrm{~s}$, annealing at $55^{\circ} \mathrm{C}$ for $30 \mathrm{~s}$ and extension $72^{\circ} \mathrm{C}$ for $1 \mathrm{~min}$, final extension at $72^{\circ} \mathrm{C}$ for $10 \mathrm{~min}$. Amplification products were separated by $1.0 \%$ agarose gel electrophoresis and visualized under UV light after staining with ethidium bromide. The amplified $16 \mathrm{~S}$ rRNA gene was sequenced using ABI 3730xl DNA Analyzer (Applied Biosystems, USA). The sequences were identified based on similarity using the Basic Local Alignment Search Tool (BLAST) program National Centre for Biotechnology Information (NCBI) online standard (http://www.ncbi. nlm.nih.gov/).

\section{Magnetic treatment of soil}

The soil was treated by magnetic field in $100 \mathrm{mT}, 300$ $\mathrm{mT}$ and $500 \mathrm{mT}$ for $5 \mathrm{~min}, 10 \mathrm{~min}, 20 \mathrm{~min}$ and $30 \mathrm{~min}$ respectively. Soybean was planted in the treated soil samples using phosphate and potash fertilizers $(75 \mathrm{mg}$ $\left.\mathrm{kg}^{-1} \mathrm{P}_{2} \mathrm{O}_{5} ; 75 \mathrm{mg} \mathrm{kg}^{-1} \mathrm{~K}_{2} \mathrm{O}\right)$. After harvestation the plants and soil was used to determine the soybean nodulation and nitrogen fixation capacities.

\section{Magnetic treatment of Paenibacillus sp.}

The Paenibacillus sp. was inoculated in $100 \mathrm{~mL}$ of YMA medium, incubated at $28^{\circ} \mathrm{C}$ for $36 \mathrm{~h}$ with agitation speed $200 \mathrm{rpm}$. The cell growth was measured by taking OD 


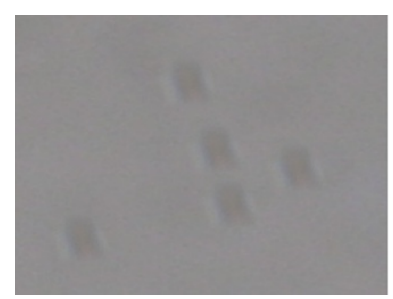

CK

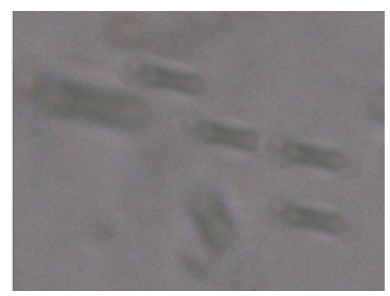

$300 \mathrm{mT} 10 \mathrm{~min}$

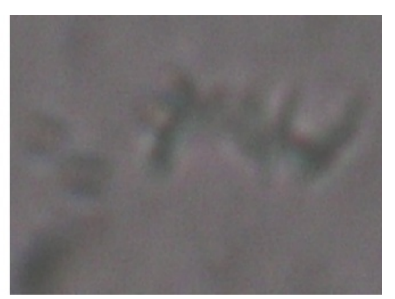

$500 \mathrm{mT} 10 \mathrm{~min}$

Figure 3 Effects of magnetic fields on the morphology of Paenibacillus sp.

at $520 \mathrm{~nm}$. After the cell growth, $25 \mathrm{~mL}$ of Paenibacillus sp. cell suspension was taken in a test tube and treated it with different magnetic fields like 100, 300 and $500 \mathrm{mT}$ with different time period such as $0,5,10,20$ and $30 \mathrm{~min}$. Each experiment was conducted in triplicates and Paenibacillus sp. without magnetic treatment was taken as control.

\section{Enzyme assay}

The Paenibacillus sp. broth was centrifuge at $5000 \times \mathrm{g}$, $4^{\circ} \mathrm{C}$ for $10 \mathrm{~min}$. After centrifugation the supernatant was discarded and the pellet was suspended in $50 \mathrm{mmol} \mathrm{L}^{-1}$ phosphate buffer ( $\mathrm{pH}$ 7.0) and then subjected to sonication. The homogenate solution was centrifuged for $10 \mathrm{~min}$ at $10000 \times \mathrm{g}, 4^{\circ} \mathrm{C}$. After centrifugation, the supernatant was used for determination of peroxidase (POD), superoxidase dismutase (SOD) and catalase (CAT) activities. Catalase activity was assay of hydrogen peroxide based on the formation of its stable complex with ammonium molkbdate and the OD was measured at $405 \mathrm{~nm}$ (Fang et al. 2004). One unit of catalase activity was defined as the decomposition of $1 \mu \mathrm{mol}$ of hydrogen peroxide per minute under standard assay conditions. Peroxidase activity was determined by hydrogen peroxide-dependent oxidation of guaiacol. Samples were mixed with guaiacol solution $(20 \mathrm{mmol} / \mathrm{L}$ guaiacol in $0.1 \mathrm{~mol} / \mathrm{L}$ phosphate buffer $(\mathrm{pH} 6.8)$ and $0.03 \%(\mathrm{v} / \mathrm{w})$ hydrogen peroxide) (Bergmeger et al. 1983). Increase in absorbance at $470 \mathrm{~nm}$ was recorded using UV-visible spectrophotometer. One unit of POD activity was defined as the change in absorbance of 0.01 per minute at room temperature. Total SOD activity was assayed by the inhibition of the photochemical reduction of pyrogallol (PAPG) by following the photo reduction of nitroblue tetrazolium (Cai et al. 2006). One unit of SOD activity was defined as amount of enzyme producing a $50 \%$ suppression of PAPG reduction. All the Enzyme specific activity is expressed as $\mathrm{U} / \mathrm{ml}$.

\section{Total nitrogen determination}

Total plant nitrogen $(\mathrm{N})$ concentration was analysed with Kjeldahl determination and colorimetric method as described by Baethgen and Alley (Baethgen \& Alley 1989). Nitrogen fixed was calculated as the total plant nitrogen content at harvest, minus the total nitrogen content at the start of the treatments.

\section{Statistical analysis}

The data obtained after experimentation was statistically evaluated using ANOVA at significance level of $p<0.05$ by using computer based programme SPSS.

\section{Results and discussion}

Molecular identification of Paenibacillus sp.

The newly isolated bacterial strain was identified by molecular techniques using 16S rDNA sequencing. Product of $1442 \mathrm{bp}$ was obtained after PCR amplification (Figure 1). The sequencing result was compared by BLAST for homology analysis. The isolated strain had 99\% similarity with Paenibacillus sp. 9-2AIA (FN397529.1), Paenibacillus sp. Gi-691 (EU497639.1), Paenibacillus chibensis strain ZYb3 (FJ432004.1), 98\% similarity with Paenibacillus sp. C-2 (KF479638.1), Paenibacillus sp. CC-YHH111 (JN806383.1), Paenibacillus sp. BM-7 (AY6-
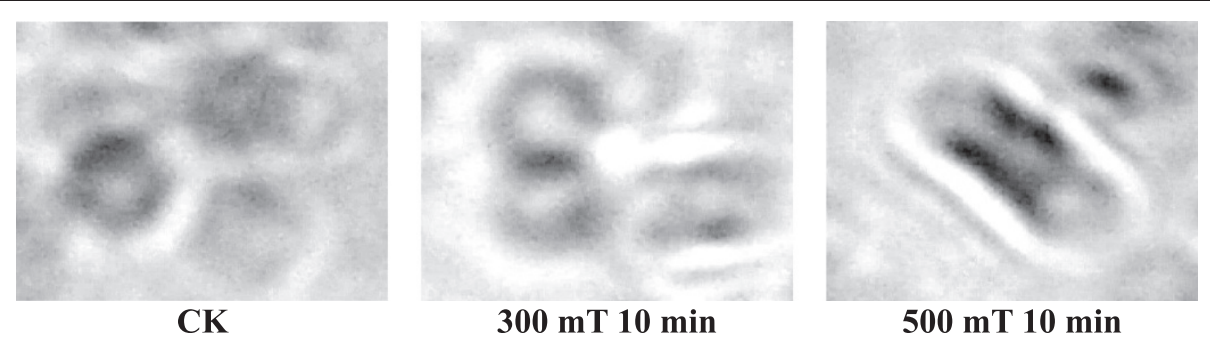

Figure 4 Effect of magnetic fields on the morphology of Paenibacillus sp.ll. 

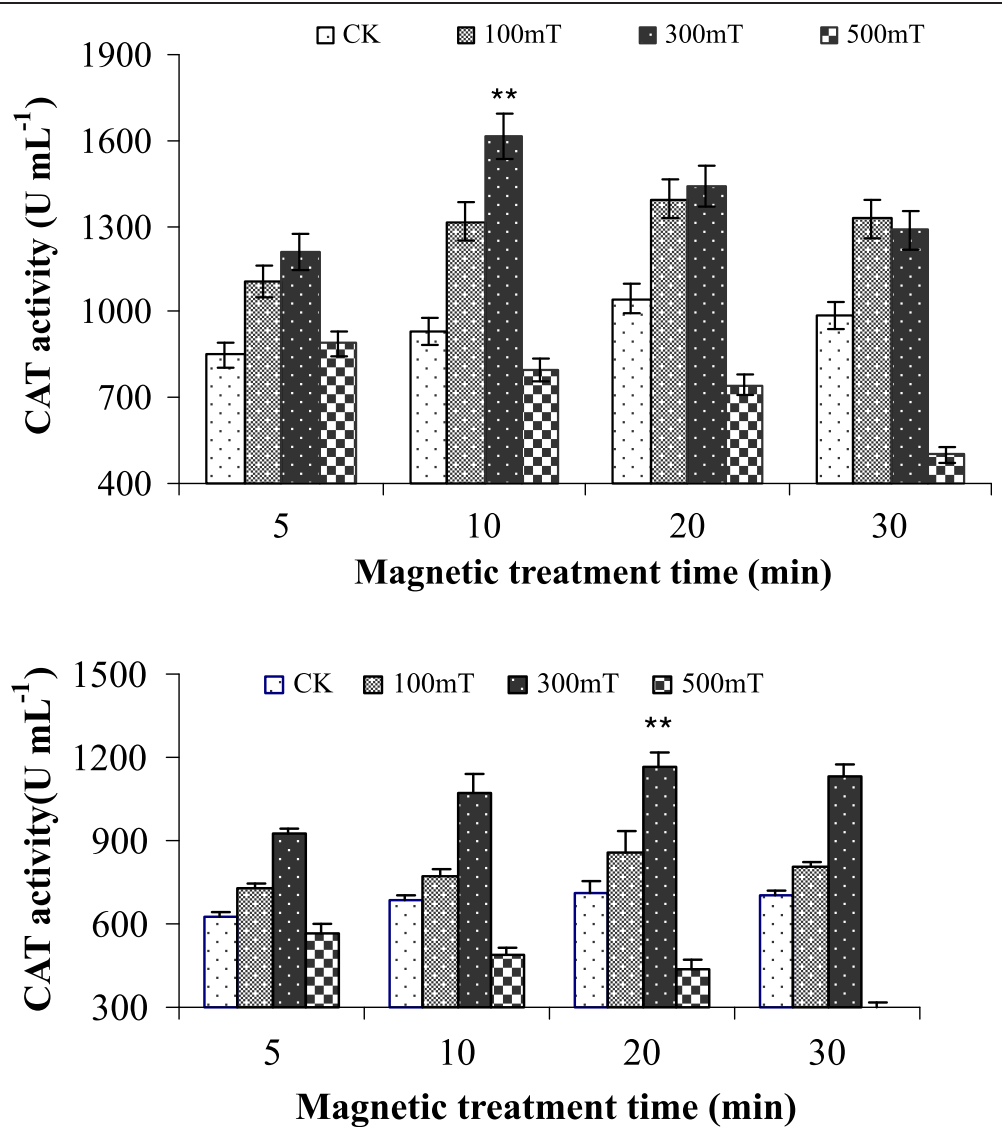

Figure 5 Effect of magnetic fields on CAT activity of Paenibacillus sp.I (upper) and Paenibacillus sp.II (lower). Error bars indicate SD among triplicates. Stars represent significance level at $P>0.05$.

35866.1), 97\% similarity with Paenibacillus sp. E18 (FJ899682.1), Paenibacillus sp. D27 (KF479657.1), Paenibacillus favisporus isolate MKI10 (EF173324.1) and 96\% similarity with Paenibacillus rhizosphaerae strain CECAP16 (AY751755.1) and Paenibacillus sp. SSG-1 (KF750627.1) as shown in phylogenetic tree (Figure 2).

\section{Effect of magnetic field treated soil soybean nodular and nitrogen fixation}

The soybean was planted in the brown soil treated with magnetic field, and the plants were harvested to measure the nodular situation and nitrogen content. The soybean was planted in the absence of nitrogen fertilizer and the difference in nitrogen content before and after treatment was used to compare the treatment effects. Thus we can use plant nitrogen to respond to the difference in the amount of nitrogen-fixing performance. Results shown in the Table 1 described that the soybean plant root dry weight, effective number of Paenibacillus sp. and total nitrogen content which treated by $100 \mathrm{mT}, 300 \mathrm{mT}$ magnetic field in plant were significantly higher as compared to control (CK). Results of this study was in agreement with Jing et al. (Jing et al. 1992) who reported that appropriate intensity of magnetic field increased 4-5 time nitrogen fixing efficiency of the Bradyrhizobium japonicum 005 . High treatment $(500 \mathrm{mT})$ of magnetic field resulted decreased number of effective rhizobia thus leading to decreased total nitrogen content. This low nitrogen content leads to less growth because nitrogen is the main nutrition factor that influences the growth in plants (Marschner 1995; Barker \& Bryson 2007). Nitrate is inorganic nitrogen which is dominant in agricultural soils and present in three or more times higher than natural soils (Hagedorn et al. 2001; Owen \& Jones 2001).

\section{Effect of magnetic treatment on generation time of Paenibacillus sp.}

In order to check the effect of magnetic field on Paenibacillus sp. morphology and physiology, all the effects were studied before and after treatment using various magnetic intensities and treatment time. After the magnetic field treatment, Paenibacillus sp. I and Paenibacillus sp. II quantity and generation time were changed. On magnetic treatment, the number of Paenibacillus sp. was increased as compared to control (CK). This effect 


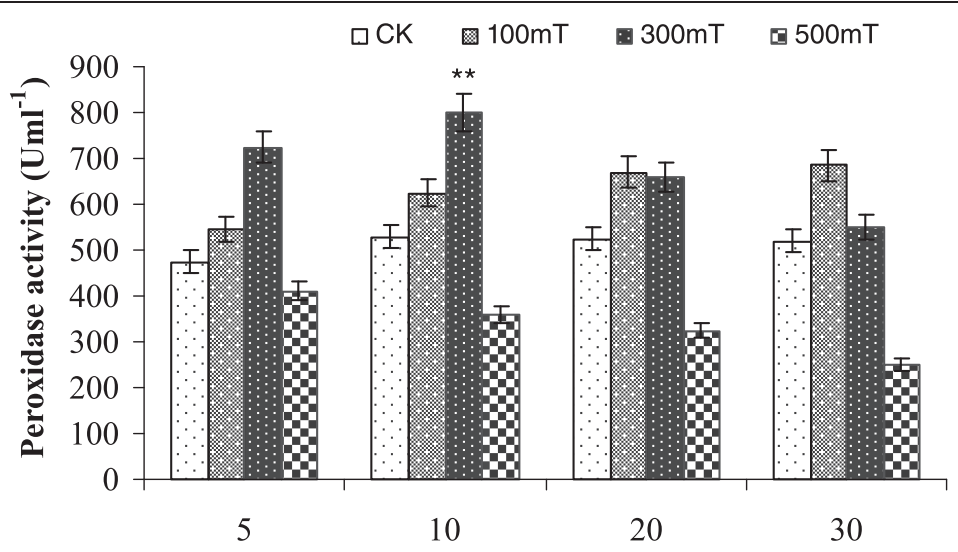

Magnetic treatment time (min)

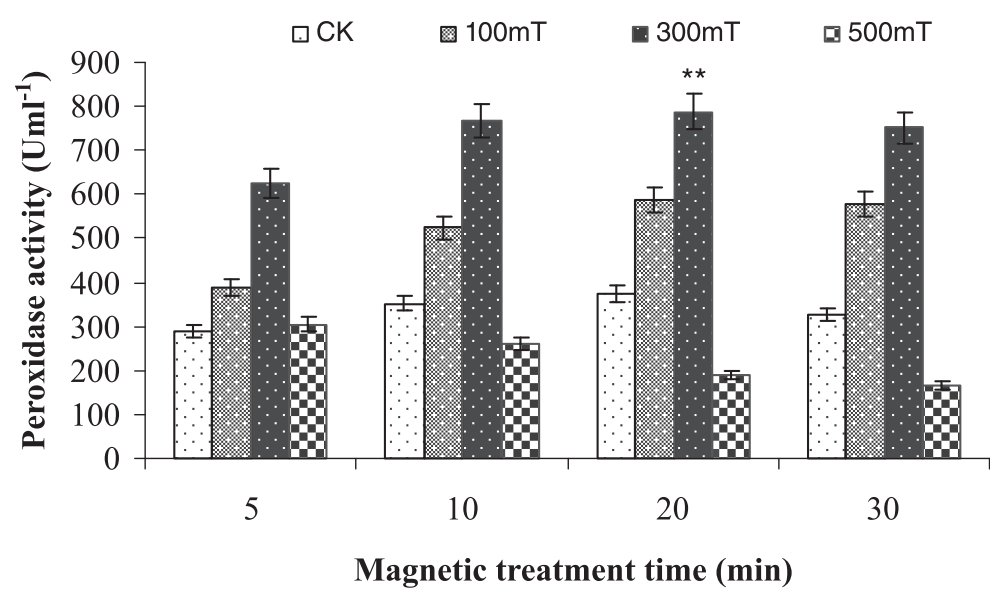

Figure 6 Effect of magnetic field on Peroxidase activity of Paenibacillus sp.l (upper) and Paenibacillus sp.Il (lower). Error bars indicate SD among triplicates. Stars represent significance level at $P>0.05$.

was changed with respect to magnetic intensity and time duration. Results (Table 2) showed that magnetic intensity of $300 \mathrm{mT}$ had strong effect on the population of Paenibacillus sp. The growth of Paenibacillus sp. was influenced by magnetic intensity and magnetic treatment time. By increasing the treatment time, number of Paenibacillus sp. was increased and further increase in treatment time resulted decline in Paenibacillus sp. growth. Of all the treatment time, 10 minutes of magnetic treatment gave better yield. The generation time of $100 \mathrm{mT}$, $300 \mathrm{mT}$ magnetic field intensity treatments were shortened as compared to control (CK) while $500 \mathrm{mT}$ magnetic field intensity treatments has no significant effect on the generation time as compared to control. These results indicated that magnetic field treatment significantly enhance the Paenibacillus sp. population in shorter time. Cheng and $\mathrm{Yi}$ (Cheng \& Yi 2009) reported that magnetic field intensity of $300 \mathrm{mT}$ had a significant positive effect on the generation time of slow-growing rhizobium (USDA110) and fastgrowing rhizobium (USDA191).
Effect of magnetic treatment on morphology of the Paenibacillus sp.

The effect of magnetic field on morphology of Paenibacillus sp. was also studied as shown in the Figures 3 and 4. Results showed that morphology of Paenibacillus sp. was affected by magnetic treatment. Only 10 minutes of magnetic treatment time with intensity of $300 \mathrm{mT}$ and $500 \mathrm{mT}$ was studied. In $300 \mathrm{mT}$ treatment the cell becomes thin and longer while in case of $500 \mathrm{mT}$ treatment the cell membrane was ruptured and the cytoplasmic sap was released leading to the death of the Paenibacillus sp. These results revealed that suitable processing time with specific intensity can promote the growth of the Paenibacillus sp. but high and long time magnetic processing inhibited the growth thus leading to the death of Paenibacillus sp. Our findings were similar as reported by Fadel et al. (Fadel et al. 2003). Various reports suggested that exposure of microorganisms to magnetic field caused changes in morphology and growth (Mohamed et al. 1997; Gaafar et al. 2006). 


\section{Effect of magnetic field treatment on enzyme activity of Paenibacillus sp.}

The influence of magnetic field was also checked on the catalase, peroxidase and superoxide dismutase activity of Paenibacillus sp. I and II. The catalases activity of Paenibacillus sp. I and II were enhanced by $300 \mathrm{mT}$ intensity as shown in Figure 5. Paenibacillus sp. I showed more catalase activity as compared to Paenibacillus sp. II. The effective intensity and magnetic treatment time for Paenibacillus sp. I and II were $300 \mathrm{mT}$ intensity for 10 and 20 minutes respectively. Both $100 \mathrm{mT}$ and $300 \mathrm{mT}$ increased the catalase activity while $500 \mathrm{mT}$ decreased catalase activity as compared to control. The highest growth rate of Paenibacillus sp. I and II was $77 \%$ and 95\% respectively. These results suggested that magnetic treatment time and intensity had strong influence on metabolic activity of Paenibacillus sp.

Figure 6 showed the influence of different magnetic field on peroxidase activity of Paenibacillus sp. The 100 and $300 \mathrm{mT}$ magnetic field treatment have growth trend to the peroxidase activity of Paenibacillus sp. The highest growth rate of Paenibacillus sp. I and II was $68 \%$ and $203 \%$ in 10 min and 30 min magnetic treatment respectively. Both Paenibacillus sp. showed maximum peroxidase activity at
10 min of treatment time with intensity of $300 \mathrm{mT}$. This activity behavior is almost similar to that of catalase activity.

Figure 7 depicted the effect of different magnetic field on superoxide dismutase activity from Paenibacillus sp. Superoxide dismutase activity was found maximum at $20 \mathrm{~min}$ of magnetic treatment with intensity of $300 \mathrm{mT}$. This enzyme activity also showed the same trend as the previous ones (catalase and peroxidase activity) but here increased treatment time resulted increased superoxide dismutase activity. In all the three enzyme activities (catalase, peroxidase and superoxide dismutase) magnetic field intensity of $500 \mathrm{mT}$ inhibited the enzyme activity because this magnetic intensity ruptured the cell shape which leads to decline in enzyme activities. The growth rate at $300 \mathrm{mT}$ magnetic treatment was $340 \%$ and $153 \%$ for Paenibacillus sp. I and II respectively. So this study was in good agreement with Liu et al. (Liu et al. 1996) who reported that appropriate magnetic field intensity enhanced the activities of hydrogen peroxidases, invertases, amylases and phosphatases in the three tested soils. Another study also revealed that magnetic field enhances the catalase and superoxide dismutase activity isolated from the roots of soybean (Celik et al. 2009).
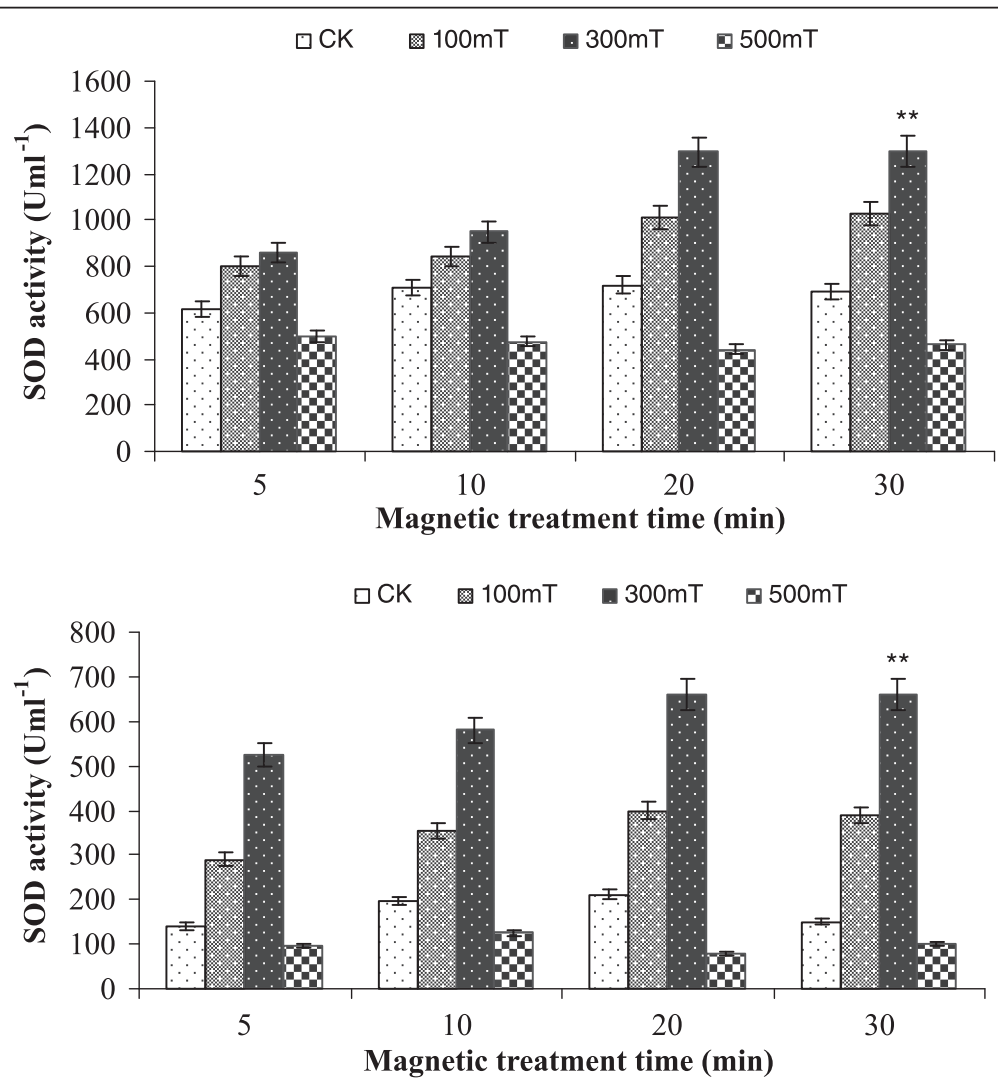

Figure 7 Effect of magnetic fields on Superoxide dismutase activity (SOD) of Paenibacillus sp.I (upper) and Paenibacillus sp.II (lower). Error bars indicate SD among triplicates. Stars represent significance level at $P>0.05$. 


\section{Conclusion}

In conclusion the magnetic treatment significantly enhances the bacterial population with shorter generation time. This increased population of Paenibacillus sp. would increase the nitrogen fixing efficiency thus leading to greater yield. The enzyme activities were also increased under the influence of magnetic treatment. Increased magnetic field intensity and longer magnetic processing time resulted ruptured bacterial cell which leads to cell death, thus reduction in nitrogen fixation efficiency. To achieve the better yield, appropriate magnetic field intensity and magnetic processing time is very important for this whole process.

\section{Competing interest}

The authors declare that they have no competing interests.

\section{Authors' contribution}

YY designed the study project, $J$, XC performed experiments and collected data, DZ performed data analysis, MI performed bioinformatics analysis and draft manuscript. All authors read and approved the final manuscript.

\section{Acknowledgment}

This study was supported by the National Natural Science Foundation of China (Grant No. 40771111) and the Shenyang agricultural university youth fund (Grant No. 20070136)

\section{Author details}

'Key Laboratory of Preservation of Northeast Cultivated Land, Ministry of Agriculture, National Engineering Laboratory for Efficient Utilization of Soil and Fertilizer, College of Land and Enviroment, Shenyang Agricultural University, 120 dongling road, Shenyang 110866, Liaoning, China. ${ }^{2}$ Liaoning Academy of Environmental Sciences, Shenyang, China. ${ }^{3}$ Bioscience and Biotechnology College, Shenyang Agricultural University, 120 dongling road, Shenyang 110866, China.

Received: 5 April 2014 Accepted: 13 January 2015

Published online: 30 January 2015

\section{References}

Agus JE, Steven DG, Brian ND (2000) Isolation and characterization of 2,3dichloro-Ipropanol-edgrading. Appl Environ Microbiol 66(7):2882-2887

Ash C, Priest FG, Collins MD (1993) Molecular identification of rRNA group 3 Bacilli (Ash, Farrow, Wallbanks and Collins) using a PCR probe test. Proposal for the creation of a new genus Paenibacillus. Antonie Van Leeuwenhoek 64:253-260

Ausubel M, Brent R, Kingston RE, Moore DD, Smit JA, Seidman JC, Struhl KS (1994) Current protocols in molecular biology, section 2.4. John Wiley and Sons, New York

Baethgen WE, Alley MM (1989) A manual colorimetric procedure for measuring ammonium nitrogen in soil and plant. Commun Soil Sci Plant Anal 20 (9\&10):961-969

Barker AV, Bryson GM (2007) Nitrogen. In: Barker AV, Pilbeam DJ (eds) Handbook of Plant nutrition. CRC Press, Boca Raton, pp 21-50

Bergmeger H, Bergmeyer J, Grabl M (1983) Methods of enzymatic Analysis, vol 3, 3rd edn. Verlag Chemie Press, Weinheim

Cai Y, Lai Z, Shen J (2006) Detection of superoxide dismutase activities in different organsim Phyllanthus emblica L. Chin J Trop Crops 27(4):29-33

Celik Ö, Büyükuslu N, Atak C, Rzakoulieva A (2009) Effects of magnetic field on activity of superoxide dismutase and catalase in Glycine max (L.) Merr. Roots. Pol J Environ Stud 18(2):175-182

Cheng X, Yi Y (2009) Effect of Magnetic Treatment on Amount and Generation Time of Slow-Growing Rhizobium (USDA110) and Fast-growing Rhizobium (USDA191). Southwest Chin J Agri Sci 22(5):1400-1403

Cheng X, Yi Y, Du A (2007) Effects of Magnetic treatment on the Azotobacter contents in brown Earth. Chin J Soil Sci 38(5):1025-1027
Fadel MA, Wael SM, Mostafa RM (2003) Effect of $50 \mathrm{~Hz}, 0.2 \mathrm{mT}$ magnetic fields on $\mathrm{RBC}$ properties and heart functions of albino rats. Bioelectromagnetics 24:535-545

Fang F, Li Y, Du GC (2004) Themo-alkali stable catalase Themoascus aurantiacus and its potential use in textile bleaching process. Chin J Biotechnol 20(3):423-428

Fisher RF, Long SR (1992) Rhizobium-plant signal exchange. Nature 357(6380):655-660

Gaafar EA, Hanafy MS, Tohamy EY, Ibrahim MH (2006) Stimulation and control of E. coli by using an extremely low frequency magnetic field. Rom J Biophys 16(4):283-296

Hagedorn F, Bucher JB, Schleppi P (2001) Contrasting dynamics of dissolved inorganic and organic nitrogen in soil and surface waters of forested catchments with Gleysols. Geoderma 100:173-192

He H, Zhu Y, Zhong K (1998) Effect of magnetic field on celhlase activity and conformation. J Jishou Univ 19(1):42-46

He H, Zhu Y, Fan Q (1999) The Effect of Magnetic Field on Escherichia Coli and Glutamic Acid Decarbolxylase. J Jishou Univ 20(3):26-29

Hua $H$, Shen Y, Wu W (2008) Effects of magnetic field on seed quality, POD and SOD of Pinus massoniana. J Nanjing For Univ 32(3):39-42

Jia Y, Ma Y, Wang Z (2002) The enzymatic activity of tomato seeds with magnetic field treatment. Biotechnology 10(2):14-17

Jing $Y$, Zhang B, Wang $Y$, Lin X (1992) Effect of magnetic field on symbiotic nitrogen fixation of soybean nodules. Acta Botanica Sinica 34(5):364-368

Lal S, Tabacchioni S (2009) Ecology and biotechnological potential of Paenibacillus polymyxa: a minireview. Indian J Microbiol 49:2-10

Lamb C, Dixon RA (1997) The oxidative burst in plant disease resistance. Annu Rev Plant Physiol Plant Mol Biol 48:251-275

Lebuhn M, Heulin T, Hartmann A (1997) Production of auxin and other indolic and phenolic compounds by Paenibacillus polymyxa strains isolated from different proximity to plant roots. FEMS Micr Eco 22:325-334

Li J, Jiao Y, Yi Y (2007) Effects of magnetic field on catalase and peroxidase activities in brown earth. J Shenyang Agric Univ 38(1):70-74

Liu XY, Yi YL, Xia LH (1996) Effect of magnetic field on enzyme activities in main soils of Northeast China. Pedosphere 6(4):341-348

Liu YH, Xu LH, Tang X (2003) The Effect of Magnetic Field Treatment on Artificially Aging Pepper Seeds. J Shandong Inst Build Mat 17(3):286-288

Mao N, Huang Y, Zhang Z (2002) Study on Biological Effect of Magnetic Resonance and Magnetized Water on Agricus bisporus Strain 176. J Fujian Teachers Univ (Nat Sci) 18(3):61-65

Marschner H (1995) Mineral Nutrition of Higher Plants. Academic Press Limited, San Diego, London

Mavingui P, Heulin T (1994) In vitro chitinase antifungal activity of a soil, rhizosphere and rhizoplane populations of Bacillus polymyxa. Soil Biol Biochem 26:801-803

McSpadden Gardener BB (2004) Ecology of Bacillus and Paenibacillus spp. in Agricultural Systems. Phytopathology 94:1252-1258

Mohamed AA, Ali FM, Gaafar EA, Magda HR (1997) Effects of magnetic field on the biophysical, biochemical properties and biological activity of Salmonella typhi., Master thesis submitted for Biophysics department, Faculty of science, Cairo University, Egypt.

Montes MJ, Mercade E, Bozal N, Guinea J (2004) Paenibacillus antarcticus sp. nov., a novel psychrotolerant organism from the Antarctic environment. Int J Syst Evol Microbiol 54:1521-1526

Ouyang J, Pei Z, Lutwick L, Dalal S, Yang L, Cassai N, Sandhu K, Hanna B, Wieczorek RL, Bluth M, Pincus MR (2008) Case report: Paenibacillus thiaminolyticus: a new cause of human infection, inducing bacteremia in a patient on hemodialysis. Ann Clin Lab Sci 38:393-400

Owen AG, Jones DL (2001) Competition for amino acids between wheat roots and rhizosphere microorganisms and the role of amino acids in plant $\mathrm{N}$ acquisition. Soil Biol Biochem 33:651-657

Pires MN, Seldin L (1997) Evaluation of Biology system for identification of strains of Paenibacillus azotofixans. Ant Van Leeu 71:195-200

Santos R, Herouart D, Sigaud S, Touati D, Puppo A (2001) Oxidative burst in alfalfa-Sinorhisobium meltloti symbiotic interaction. Mol Plant Micobe Interact 14(1):86-89

Sawada H, Kuykendall LD, Young JM (2003) Changing concepts in the systematics of bacterial nitrogen-fixing legume symbionts. J Gen Appl Microbiol 49(3):155-79

Sierra S, Rodelas B, Martinez-Toledo MV, Pozo C, González-López J (1999) Production of B-group vitamins by two Rhizobium stains in chemically defined media. J Appl Microbiol 86:851-858 
Vincent JM (1970) A Manual for the Practical Study of Root-Nodule Bacteria. Blackwell Scientific, Oxford, IBP Handbook, 15

Von der Weid I, Alviano DS, Santos ALS, Soares RMA, Alviano CS, Seldin L (2003) Antimicrobial activity of Paenibacillus peoriae against a broad spectrum of phytopathogenic bacteria and fungi. J Appl Microbiol 95:1143-1151

Yan L, Zhu Y, He S, Cao Z (1997) Effect of static magnetic field on activity of immobilized a-amylase. Chinese Sci Bull 42(2):127-130

Zhu Y, Zhong K, He S (1996) Efect of Magnetic Field on Activity of Immobilized LDH. J Hunan Univ 23(5):57-61

Submit your manuscript to a SpringerOpen ${ }^{\odot}$ journal and benefit from:

- Convenient online submission

- Rigorous peer review

- Immediate publication on acceptance

- Open access: articles freely available online

- High visibility within the field

- Retaining the copyright to your article

Submit your next manuscript at $\gg$ springeropen.com 